\title{
Acute effects of whey protein on energy intake, appetite and gastric emptying in younger and older, obese men
}

Avneet Oberoi ${ }^{1}$, Caroline Giezenaar $\mathbb{E}^{2}$, Caroline Jensen ${ }^{3}$, Kylie Lange ${ }^{1}$, Trygve Hausken ${ }^{4}$, Karen L. Jones ${ }^{1}$, Michael Horowitz ${ }^{1}$, lan Chapman ${ }^{1}$ and Stijn Soenen (D) $^{1,5}$

\begin{abstract}
Background: Obesity is becoming more prevalent in older people. A management strategy in obese, young adults is to increase dietary protein relative to other macronutrients. It is not clear if this is effective in obese, older individuals. Obesity may be associated with diminished sensitivity to nutrients. We have reported that a 30-g whey protein drink slows gastric emptying more, and suppresses energy intake less, in older, than younger, non-obese men. The aim of this study was to determine the effect of a $30 \mathrm{~g}$ whey protein drink on energy intake, GE and glycaemia in obese, older and younger men.
\end{abstract}

Methods: In randomized, double-blind order, 10 younger (age: $27 \pm 2$ years; BMl: $36 \pm 2 \mathrm{~kg} / \mathrm{m}^{2}$ ), and 10 older $(72 \pm$ 1 years; $33 \pm 1 \mathrm{~kg} / \mathrm{m}^{2}$ ), obese men were studied twice. After an overnight fast, subjects ingested a test drink containing $30 \mathrm{~g}$ whey protein $(120 \mathrm{kcal})$ or control $(2 \mathrm{kcal})$. Postprandial gastric emptying (antral area, 2D Ultrasound) and blood glucose concentrations were measured for $180 \mathrm{~min}$. At $t=180 \mathrm{~min}$ subjects were given a buffet meal and ad libitum energy intake was assessed.

Results: Older subjects ate non-significantly less $(\sim 20 \%)$ that the younger subjects (effect of age, $P=0.16$ ). Whey protein had no effect on subsequent energy intake ( $\mathrm{kcal}$ ) compared to control in either the younger (decrease $3 \pm 8 \%$ ) or older (decrease $2 \pm 8 \%$ ) obese men (age effect $P>0.05$, protein effect $P=0.46$, age $\times$ protein interaction effect $P=$ 0.84). Whey protein slowed gastric emptying, to a similar degree in both age groups (50\% emptying time: control vs. protein young men: $255 \pm 5$ min vs. $40 \pm 7$ min; older men: $16 \pm 5$ min vs. $50 \pm 8$ min; protein effect $P=0.001$, age effect $P=0.93$, age $\times$ protein interaction effect $P=0.13$ ).

Conclusions: Our data suggest that obesity may blunt/abolish the age-related effect of whey protein on suppression of energy intake.

\section{Introduction}

While the number of older people is increasing worldwide $^{1,2}$, it is not as well appreciated that obesity rates are

Correspondence: Stijn Soenen (stijn.soenen@adelaide.edu.au)

${ }^{1}$ Adelaide Medical School and Centre of Research Excellence in Translating Nutritional Science to Good Health, The University of Adelaide, Adelaide, Royal Adelaide Hospital, South-Australia, SA, Australia

${ }^{2}$ Riddet Institute, Massey University, Palmerston North, New Zealand

Full list of author information is available at the end of the article rising across the age range. Approximately one-third of people over 65 years are obese (body mass index (BMI) > $\left.30 \mathrm{~kg} / \mathrm{m}^{2}\right)$ in Australia $^{3}$ and other developed countries (US, UK etc) ${ }^{4,5}$ and this proportion is increasing. Although the BMI range associated with lowest morbidity and mortality increases with age ${ }^{6}$, a BMI higher than $30 \mathrm{~kg} / \mathrm{m}^{2}$ in older people is still associated with adverse health outcomes, including diabetes, hypertension and heart disease. Obesity is therefore a serious problem in 
older people $\mathrm{e}^{7-10}$ and intentional weight loss is often recommended for obese, older adults ${ }^{11}$.

Ageing is also associated with changes in feeding behaviour, gut function, and body composition, which impact on life expectancy and quality ${ }^{12-17}$. Skeletal muscle mass decreases, while fat mass increases ${ }^{18}$. Insufficient protein intake in obese older individuals exacerbates muscle loss ${ }^{19}$. This muscle loss, which may lead to sarcopaenia, is associated with functional impairment, increased rates of falls, increased nursing home admissions, and other adverse outcomes ${ }^{10,20-26}$.

Protein supplements, often rich in whey protein, are commonly part of weight-loss strategies, based on the rationale that protein is more satiating than the other macronutrients ${ }^{27-30}$, although that effect may be modest, particularly when the protein is consumed as part of typical, ad libitum eating situations. Whey protein is high in essential amino acids which are rapidly digested, resulting in postprandial amino acid availability, stimulating muscle protein accretion more effectively than casein and casein hydrolysate in older men ${ }^{31,32}$. We have recently shown that the acute administration of $30 \mathrm{~g}$ $(120 \mathrm{kcal})$ and $70 \mathrm{~g}(280 \mathrm{kcal})$ oral whey-protein loads suppressed subsequent energy intake by $12-17 \%$ in young people without suppression in healthy older men ${ }^{33}$. The whey-induced suppression of appetite and energy intake in young people may reflect an increase in pyloric and reduction in antral and duodenal motility, factors important in the regulation of gastric emptying ${ }^{34,35}$. Obesity appears to have minor, inconsistent, effects on gastric emptying ${ }^{36-38}$, whereas gastric emptying is modestly slower in older, than younger, adults ${ }^{33}$. The potential influence of gastric emptying and energy/ protein load of an ingested meal on subsequent voluntary food intake is complex and likely to depend on the time of subsequent eating, the degree of gastric distension and initiation of small intestinal mechanisms to stimulate satiety after food leaves the stomach ${ }^{37,39,40}$.

Information about the effects of whey protein on energy intake in obese, older people is limited. We have reported that the acute suppression of energy intake by whey protein, administered either intraduodenally ${ }^{17}$, or orally ${ }^{33}$, is less in healthy, non-obese, older than younger men, suggesting that the use of protein supplements to promote weight loss may not be as affective in older as younger adults ${ }^{33}$. However, ad libitum energy intake responses to oral whey protein have not been evaluated in older, obese, adults. These may have implications for the use of high protein dietary strategies to manage obesity and maintain muscle mass in older people.

The primary aim of this study was to determine the effects of a $30 \mathrm{~g}$ whey protein drink on energy intake in obese older and younger men.

\section{Materials and methods}

Ten younger [Mean \pm standard error of mean (SEM): age: $27 \pm 2$ years; body weight: $112 \pm 8 \mathrm{~kg}$; height: $1.75 \pm$ $2.81 \mathrm{~m}$; BMI: $36 \pm 2 \mathrm{~kg} / \mathrm{m}^{2}$ ] and ten older (age: $72 \pm 1$ years; body weight: $103 \pm 4 \mathrm{~kg}$; height: $1.76 \pm 2.56 \mathrm{~m}$; BMI: $33 \pm 1 \mathrm{~kg} / \mathrm{m}^{2}$ ) obese men were recruited by advertisement. Body weight and BMI of the younger and older subjects did not differ significantly $(P>0.05)$.

On the basis of our previous study in lean subjects ${ }^{17}$, we determined that ten subjects/group would be sufficient to detect a difference in the suppression of energy intake by $30 \mathrm{~g}$ whey protein of $395 \mathrm{kcal}$, with standard deviations (SDs) of $316 \mathrm{kcal}$ (younger subjects) and $180 \mathrm{kcal}$ (older subjects) ${ }^{17}$, and in $50 \%$ gastric emptying time (T50 min) of $80 \mathrm{~min}$ with (SD's) of $38 \mathrm{~min}$ (younger subjects) and 63 min (older subjects) ${ }^{41-43}$, between younger and older subjects, with $\alpha=0.05$ and power of $80 \%$.

Subjects were excluded on the basis of smoking, alcohol abuse, diabetes $(\mathrm{HbA} 1 \mathrm{C}>6 \%)$, significant gastrointestinal surgery, gastrointestinal symptoms (pain, reflux, diarrhoea, or constipation), and the use of medications known to affect energy intake, appetite, or gastrointestinal motor function. For older people, additional exclusion criteria were impaired cognitive function (score $<25$ on Mini Mental State ${ }^{44}$ ) and depression (score $\geq 11$ on the Geriatric Depression Questionnaire ${ }^{45}$ ).

The Royal Adelaide Hospital Human Research Ethics Committee approved the protocol which was conducted in accordance with the Declaration of Helsinki. The study was registered with the Australian New Zealand Clinical Trial Registry (www.anzctr.org.au, registration number ANZCTR12616001216404). All subjects provided written informed consent prior to their study inclusion.

\section{Protocol}

Subjects were studied twice, separated by $\geq 3$ days, to determine the effects of a whey protein drink $(30 \mathrm{~g} /$ $120 \mathrm{kcal})$ and a control drink ( $\sim 0 \mathrm{~g}$ whey protein $/ \sim 2 \mathrm{kcal})$ on energy intake, in randomized order ( 1 block with balanced permutations; www.randomization.com), double-blind, and cross-over design.

The protein drink $(\sim 450 \mathrm{~mL})$ was prepared by dissolving whey protein (Bulk Nutrients, Tasmania, Australia) in demineralized water and diet lime cordial (Bickford's Australia, South Australia (SA), Australia) to achieve the desired load [i.e. $30 \mathrm{~g}$ whey (volume of the powder: $19 \mathrm{~mL}$ ) in $335 \mathrm{~mL}$ distilled water and $85 \mathrm{~mL}$ cordial $(2.5 \mathrm{kcal} /$ $100 \mathrm{~mL}$ ). The 'control' drink contained $0 \mathrm{~g}$ protein, $360 \mathrm{~mL}$ water, and $90 \mathrm{~mL}$ cordial. Sodium chloride, $0.3 \mathrm{~g}$ and $1.2 \mathrm{~g}$, was added to the whey and control drinks so that the osmolarity $(88 \mathrm{mOsm} / \mathrm{L})$ was matched. To ensure even mixing drinks were stirred continuously at low speed on a stirring plate. The volumes of the drinks differed 
slightly (control: $450 \mathrm{~mL} ; 30 \mathrm{~g}$ protein: $439 \mathrm{~mL}$ ). Drinks were prepared by a research officer not involved in data analysis and served in a covered cup, so that both investigators and subjects were blinded to the treatment.

Subjects were provided with a standardized meal [beef lasagne (McCain Foods Pty Ltd, Wendouree, Victoria (VIC), Australia), $\sim 591 \mathrm{kcal}]$ to consume on the night before each study day at $\sim 1900 \mathrm{~h}$. They were instructed to fast overnight $\sim 12 \mathrm{~h}$ from solids and liquids except water, and to refrain from strenuous physical activity until they attended the laboratory at $\sim 0830 \mathrm{~h}$.

On arrival, subjects were seated in a chair, where they remained throughout the study day, and an intravenous cannula was inserted. Measurements of antral area and perceptions of appetite and gastrointestinal symptoms were performed immediately before (during fasting; $0 \mathrm{~min}$ ), immediately after ingestion of the drink ( $5 \mathrm{~min})$, and then at $15 \mathrm{~min}$ intervals until $180 \mathrm{~min}$. Subjects consumed the drink within $2 \mathrm{~min}$. Antral area was measured by 2 -dimensional (2D) ultrasonography ${ }^{33}$. Perceptions of appetite and gastrointestinal symptoms were assessed using visual analogue scales (VAS) and blood samples were collected to measure blood glucose. At $180 \mathrm{~min}$, subjects were given a cold, buffet-style meal, as described $^{33}$, in excess of what they were expected to consume (total energy content of 2,457 kcal; $19 \%$ protein, $50 \%$ carbohydrates, $31 \%$ fat) and instructed to eat freely for up to $30 \mathrm{~min}$ until comfortably full $(180-210 \mathrm{~min})^{33}$.

\section{Measurements \\ Energy intake}

The amount eaten (g) was quantified by weighing the meal before and after consumption. Energy intake (kcal) and proportions of intake of protein, carbohydrate, and fat were calculated using commercially available software (Foodworks; 3.01, Xyris Software, Highgate Hill, Queensland, Australia). Energy intake was calculated both as intake at the buffet meal and as the cumulative energy intake (sum of energy intake at the buffet meal and from the preload drink). Absolute ( $\mathrm{kcal}$ ) and percentage suppression/change (energy intake as \% of control day intake) of energy intake at the buffet meal by $30 \mathrm{~g}$ protein compared with control were calculated $^{16}$.

\section{Gastric emptying}

Gastric emptying was measured at baseline, after overnight fasting $(t=0 \mathrm{~min})$, immediately after drink consumption and then every $15 \mathrm{~min}$ to $180 \mathrm{~min}$. Gastric emptying rates were calculated from ultrasound measurements of gastric antral area $\left(\mathrm{cm}^{2}\right)$, as previously descri$\operatorname{bed}^{40,46}$. Measurements were performed with a Logiq ${ }^{\text {TM }}$ ultrasound machine (GE Healthcare Technologies, Sydney, New South Wales, Australia) using a $3.5 \mathrm{C}$ broad spectrum $2.5-4 \mathrm{MHz}$ convex linear array transducer. The transducer was positioned vertically to obtain a para-sagittal image of the antrum with the superior mesenteric vein and the abdominal aorta in a longitudinal section. Measurements were performed at the end of inspiration. To calculate meal retention in the stomach, fasting antral area (measured at baseline) was subtracted from subsequent measurements performed after ingestion of the drinks ${ }^{46}$. Gastric retention was calculated as

$$
\text { Retention }(\%)=[\mathrm{AA}(\mathrm{t})-\mathrm{AA}(\mathrm{f})] /[] \mathrm{AA}(\max )-\mathrm{AA}(\mathrm{f})^{*} 100
$$

where $\mathrm{AA}(\mathrm{t})=$ antral area measured at a given time, AA $(\mathrm{f})=$ fasting antral area, and $\mathrm{AA}(\max )=$ maximum antral area recorded after drink ingestion ${ }^{46}$. When ultrasound images lacked sufficient clarity, data were imputed by linear interpolation. The time at which $50 \%$ of the preload drink had emptied from the stomach (time to halving of post-drink maximum antral area: $\mathrm{T} 50$; $\mathrm{min}$ ) was calculated for both conditions.

\section{Perceptions of appetite and gastrointestinal symptoms}

Perceptions of hunger, desire to eat, prospective consumption, fullness, nausea, and bloating were rated using a $100 \mathrm{~mm}$ visual analogue scale (VAS) questionnaire at $t=0,5,15,30,45,60,75,90,105,120,135,150,165,180$, and $210 \mathrm{~min}$ as previously described ${ }^{47}$. Area under the curve (AUC) was calculated for appetite ratings $(0-180 \mathrm{~min})$ using the trapezoidal rule.

\section{Blood glucose}

Blood glucose concentrations $(\mathrm{mmol} / \mathrm{L})$ were determined by the glucose oxidase method using a portable glucometer (Optium Xceed, Abbott Laboratories, Australia). Area under the curve (AUC) was calculated for blood glucose 0-180 min using the trapezoidal rule.

\section{Data and statistical analysis}

Statistical analyses were performed using SPSS software (version 25; IBM, Armonk, NY, USA). Effects of age and treatment and their interaction effect were determined using a repeated measures mixed-effects model. An unstructured covariance structure was used to account for the repeated treatments by subject. Suppression of energy intake by protein and outcomes of the control condition were compared between age groups with a paired $t$-test. Statistical significance was accepted at $P<0.05$. All data are presented as mean values \pm SEM.

\section{Results}

The study protocol was well tolerated by all subjects.

\section{Energy intake}

Older subjects consumed $\sim 20 \%$ less energy after the drinks than younger subjects, although this difference was 


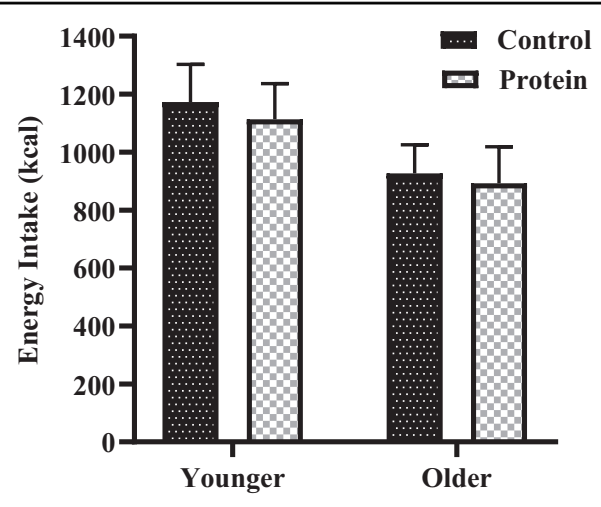

Fig. 1 Mean \pm standard error of mean (SEM) energy intake at the buffet meal (kcal) in younger $(n=10)$ and older $(n=10)$ men after drinks containing water (control-black) and $30 \mathrm{~g}$ whey protein (black border). Main age and protein effects and age $\times$ protein interaction effect were determined by using mixed model analysis. The protein drink did not suppress subsequent energy intake at the buffet meal compared with control. The main effects of age $(P=0.16)$ and protein $(P=0.46)$ and the age $\times$ protein interaction effect $(P=0.84)$ for energy intake were not significant.

not statistically significant $(P=0.16)$. There was no difference in the amount of energy consumed after the protein drink compared to control, in either younger (control $1173 \pm 130 \mathrm{kcal}$ vs. protein $1114 \pm 124 \mathrm{kcal}$ ) or older (control $926 \pm 99 \mathrm{kcal}$ vs. protein $892 \pm 127 \mathrm{kcal}$ ) men (age effect $P=0.16$, protein effect $P=0.46$, age $\times$ protein interaction effect $P=0.84$; Fig. 1 ).

There was no suppression of energy intake by whey protein in either age group (younger $-3.0 \pm 7.7 \%$ vs. older $-2.3 \pm 8.4 \%, P=0.95$ ).

Furthermore, cumulative energy intake (intake at buffet meal plus test drink) during the protein day did not differ with age or treatment (age effect $P=0.16$, protein effect $P=0.25$, age $\times$ protein interaction effect $P=0.84$ ).

\section{Gastric emptying}

In one older subject the quality of antral images was insufficient to determine gastric emptying on both days, so data for this subject were excluded from analysis. There was no difference in baseline (after overnight fasting) antral areas between age groups or study treatments (young men control vs. protein: $3.20 \pm 0.37 \mathrm{~cm}^{2}$ vs. $2.98 \pm$ $0.31 \mathrm{~cm}^{2}$; older men control vs. protein: $2.68 \pm 0.29 \mathrm{~cm}^{2}$ vs. $3.19 \pm 0.29 \mathrm{~cm}^{2}$; age effect $P=0.64$, protein effect $P=$ 0.61 , age $\times$ protein interaction effect $P=0.23$ ).

The protein drink emptied more slowly than control in both groups (T50 young men control vs. protein: $25 \pm$ $5 \mathrm{~min}$ vs. $40 \pm 7 \mathrm{~min}$; older men control vs. protein: $16 \pm$ $5 \mathrm{~min}$ vs. $50 \pm 8 \mathrm{~min}$; protein effect $P=0.001$, age effect $P=0.93$, age $\times$ protein interaction effect $P=0.13$; Fig. 2). Gastric emptying of the control drink was not significantly different between both age groups $(P=0.21)$.

\section{Blood glucose concentrations}

Fasting blood glucose concentrations were higher in older (control $6.1 \pm 0.2 \mathrm{mmol} / \mathrm{L}$, protein $6.2 \pm 0.2 \mathrm{mmol} / \mathrm{L}$ ) than younger (control $5.4 \pm 0.1 \mathrm{mmol} / \mathrm{L}$, protein $5.4 \pm 0.2 \mathrm{mmol} / \mathrm{L}$ ) men (age effect $P=0.003$, protein effect $P=0.76$, age $\times$ protein interaction effect $P=0.58$ ) and throughout both study days (AUC 0-180 min, young men control: $1003 \pm$ $17 \mathrm{mmol} / \mathrm{L}$, protein: $981 \pm 21 \mathrm{mmol} / \mathrm{L}$; older men control: $1112 \pm 28 \mathrm{mmol} / \mathrm{L}$, protein: $1108 \pm 37$, age effect $P=0.005$ ). There was no effect of protein on blood glucose concentrations in either age group (protein effect $P=0.42$, age $\times$ protein interaction effect $P=0.54$; Fig. 3 ).

\section{Perceptions of appetite and gastrointestinal symptoms Baseline}

Baseline ratings of hunger [younger men control (YC) $53 \pm 9 \mathrm{~mm}$, younger men protein (YP) $39 \pm 9 \mathrm{~mm}$; older men control (OC): $37 \pm 9 \mathrm{~mm}$, older men protein (OP) $44 \pm 6 \mathrm{~mm}$ ), fullness (YC $19 \pm 5 \mathrm{~mm}$, YP $20 \pm 6 \mathrm{~mm}$; OC $16 \pm 6 \mathrm{~mm}$, OP $9 \pm 5 \mathrm{~mm}$ ), nausea (YC $14 \pm 6 \mathrm{~mm}$, YP $8 \pm$ $4 \mathrm{~mm}$; OC $4 \pm 1 \mathrm{~mm}$, OP $5 \pm 1 \mathrm{~mm}$ ) and bloating (YC $8 \pm$ $3 \mathrm{~mm}$, YP $9 \pm 5 \mathrm{~mm}$; OC $7 \pm 4 \mathrm{~mm}$, OP $5 \pm 1.9 \mathrm{~mm}$ ) were not different between younger and older men or between control and protein days (all main effects $P>0.05$ ).

There were significant but modest age $\times$ protein interaction effects for ratings of prospective consumption and desire to eat at baseline. Pairwise comparisons for prospective food consumption (age $\times$ protein interaction effect $P=0.001$ ) showed that in the young, scores were higher on the control day than protein day, whereas in the older group, scores were higher on the protein day than control day (YC $62 \pm 8 \mathrm{~mm}$, YP $51 \pm 8 \mathrm{~mm}, P=0.040$ vs. OC $41 \pm 8 \mathrm{~mm}$, OP $58 \pm 8 \mathrm{~mm}, P=0.004)$.

For desire to eat (age $\times$ protein interaction effect $P=$ 0.020 ), there was no difference between treatments in either age group $(P>0.05)$. Scores were higher in the younger than the older group on the control day $(P=$ 0.040 ), but not on the protein day (YC $52 \pm 8 \mathrm{~mm}$, YP $39 \pm 7 \mathrm{~mm}$ vs. OC $30 \pm 7 \mathrm{~mm}$, OP $39 \pm 7 \mathrm{~mm}, P=0.98$ ).

\section{After study drink}

Prospective food consumption The main age and protein effects for ratings of desire to eat (total AUC; YC $10,019 \pm 1174 \mathrm{~mm} \cdot \mathrm{min}$, YP $8,925 \pm 1156 \mathrm{~mm} \cdot \mathrm{min}$ vs. OC $6,003 \pm 1173 \mathrm{~mm}$.min, OP 6,763 $\pm 1156 \mathrm{~mm}$.min; age effect $P=0.07$, protein effect $P=0.71$ ), hunger (YC 10,041 \pm $1180 \mathrm{~mm} . \mathrm{min}$, YP $8,676 \pm 1289 \mathrm{~mm} . \mathrm{min}$ vs. OC $5,873 \pm$ $1180 \mathrm{~mm} . \mathrm{min}$, OP $6,324 \pm 1289 \mathrm{~mm} . \mathrm{min}$; age effect $P=$ 0.07 , protein effect $P=0.35$ ), fullness (YC 4,705 $\pm 897 \mathrm{~mm}$. $\mathrm{min}$, YP 4,703 $\pm 959 \mathrm{~mm} . \mathrm{min}$ vs. OC 4,884 $\pm 897 \mathrm{~mm}$.min, OP $4,703 \pm 959 \mathrm{~mm} . \mathrm{min}$; age effect $P=1.0$, protein effect $P=0.57$ ), prospective food consumption (YC 10,279 \pm $1198 \mathrm{~mm}$.min, YP $9,572 \pm 1143 \mathrm{~mm} \cdot \mathrm{min}$ vs. OC $7,341 \pm$ $1198 \mathrm{~mm} . \mathrm{min}$, OP 7,607 $\pm 1143 \mathrm{~mm} . \mathrm{min} ; \quad$ age effect 

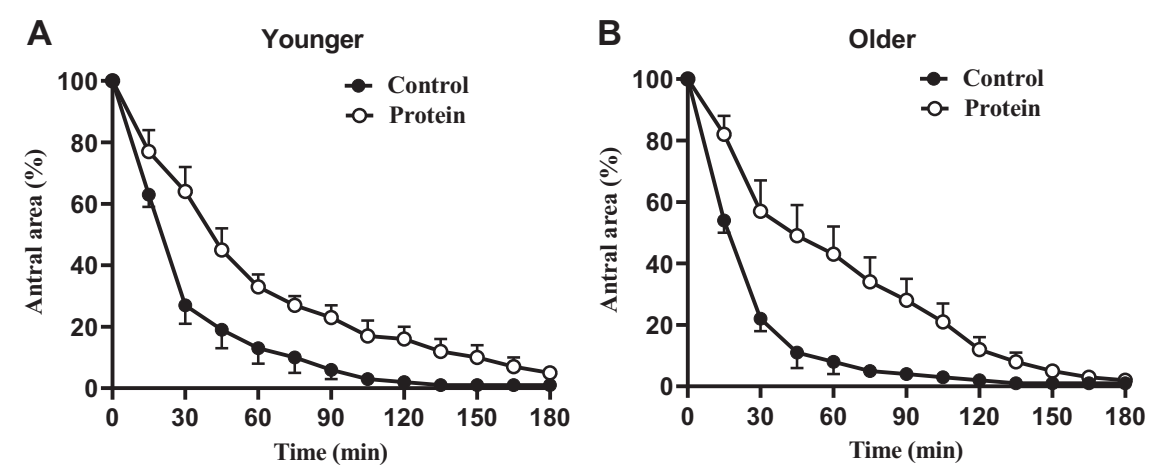

Fig. 2 Mean \pm standard error of mean (SEM) antral area $(\%)$ in younger $(n=10)$ and older $(n=10)$ men after drinks containing water (control) and $\mathbf{3 0} \mathbf{g}$ whey protein. Main age and protein effects and age x protein interaction effect were determined by using mixed effects analysis. Gastric emptying (antral area) of the protein drink was slower than control to a similar degree in both the age groups. The main effect of protein for $50 \%$ gastric emptying time (T50 min; $P=0.001$ ) was significant; the age ( $P=0.93)$ and the age $\times$ protein interaction $(P=0.13)$ effects were not significant.
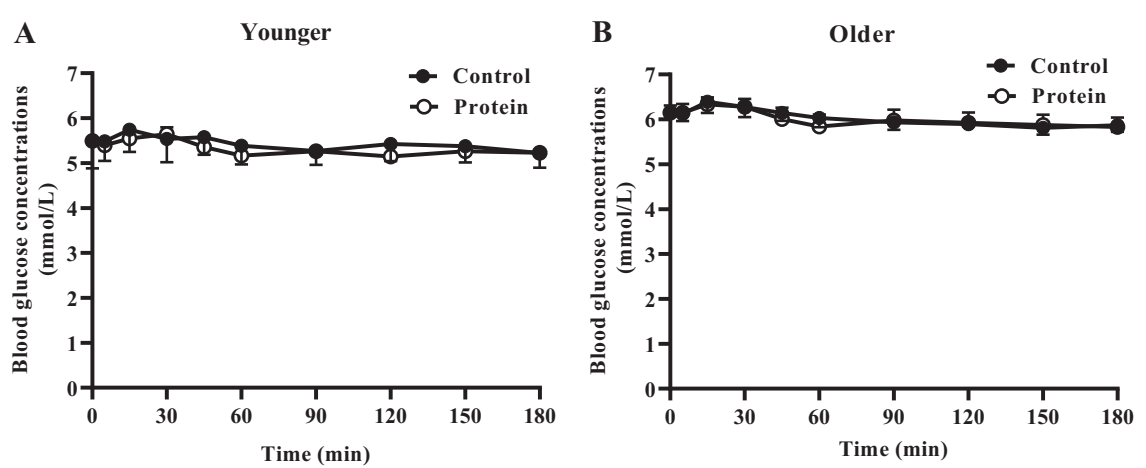

Fig. 3 Mean \pm standard error of mean (SEM) blood glucose concentrations (mmol/L) in younger $(n=10)$ and older $(n=10)$ men after drinks containing water (control) and $\mathbf{3 0} \mathbf{g}$ whey protein. Main age and protein effects and age $\times$ protein interaction effect were determined by using mixed effects analysis. There was no effect of protein on the blood glucose concentrations in either age group. The main effect of age $(P=0.005)$ was significant; the protein $(P=0.42)$ and age $\times$ protein interaction $(P=0.54)$ effects were not significant.

$P=0.15$, protein effect $P=0.57$ ), bloating (YC 3,151 \pm $875 \mathrm{~mm} \cdot \mathrm{min}$, YP $2,666 \pm 653 \mathrm{~mm} \cdot \mathrm{min}$ vs. OC $1,973 \pm$ $875 \mathrm{~mm} . \mathrm{min}$, OP $1,495 \pm 653 \mathrm{~mm}$.min; age effect $P=0.28$, protein effect $P=0.11$ ) were not significant. In younger subjects nausea ratings were higher after the test drink than older subjects (YC 3,127 $\pm 741 \mathrm{~mm} . \mathrm{min}, \mathrm{YP} 2,892 \pm 827 \mathrm{~mm}$. min vs. OC $771 \pm 741 \mathrm{~mm} . \mathrm{min}$, OP $708 \pm 827 \mathrm{~mm}$.min; age effect $P=0.04)$. The effect of protein was not significant $(P=0.74)$.

The age $\times$ protein interaction effect for ratings of hunger, fullness, prospective food consumption, nausea, and bloating were not significant $(P>0.05)$, although there was a strong trend for desire to eat to be less in the older subjects (age $\times$ protein interaction effect $P=0.051$; Fig. 4).

\section{Discussion}

The major findings of this study are:

1. There was no suppression of ad libitum energy intake after $30 \mathrm{~g}$ whey protein ingestion in either older or young, obese men. This is in contrast to our previous studies in lean, non-obese men, where greater (and significant) suppression of energy intake was observed in younger than older men, after both a $30 \mathrm{~g}$ whey protein drink (1\% vs. $15 \%$ suppression) $)^{33}$ and intraduodenal whey infusions ( $1 \%$ vs. $19 \%$ suppression $)^{17}$.

2. The whey protein drink slowed gastric emptying, to a comparable degree in both age groups.

3. There was no effect of the protein drink on hunger, desire to eat, fullness, satiety and bloating.

Numerous studies, including our own, have shown that ingestion of protein, by mouth and directly into the stomach or small intestine, acutely suppresses appetite and ad libitum energy intake in young, non-obese adults. Evidence that protein is the most satiating of the macronutrients in young adults $^{27,28}$, has led to the development of high protein (usually energy-restricted) diets and their recommendation to young, overweight people trying to lose weight. Increased protein intake in these diets is often at the expense of 


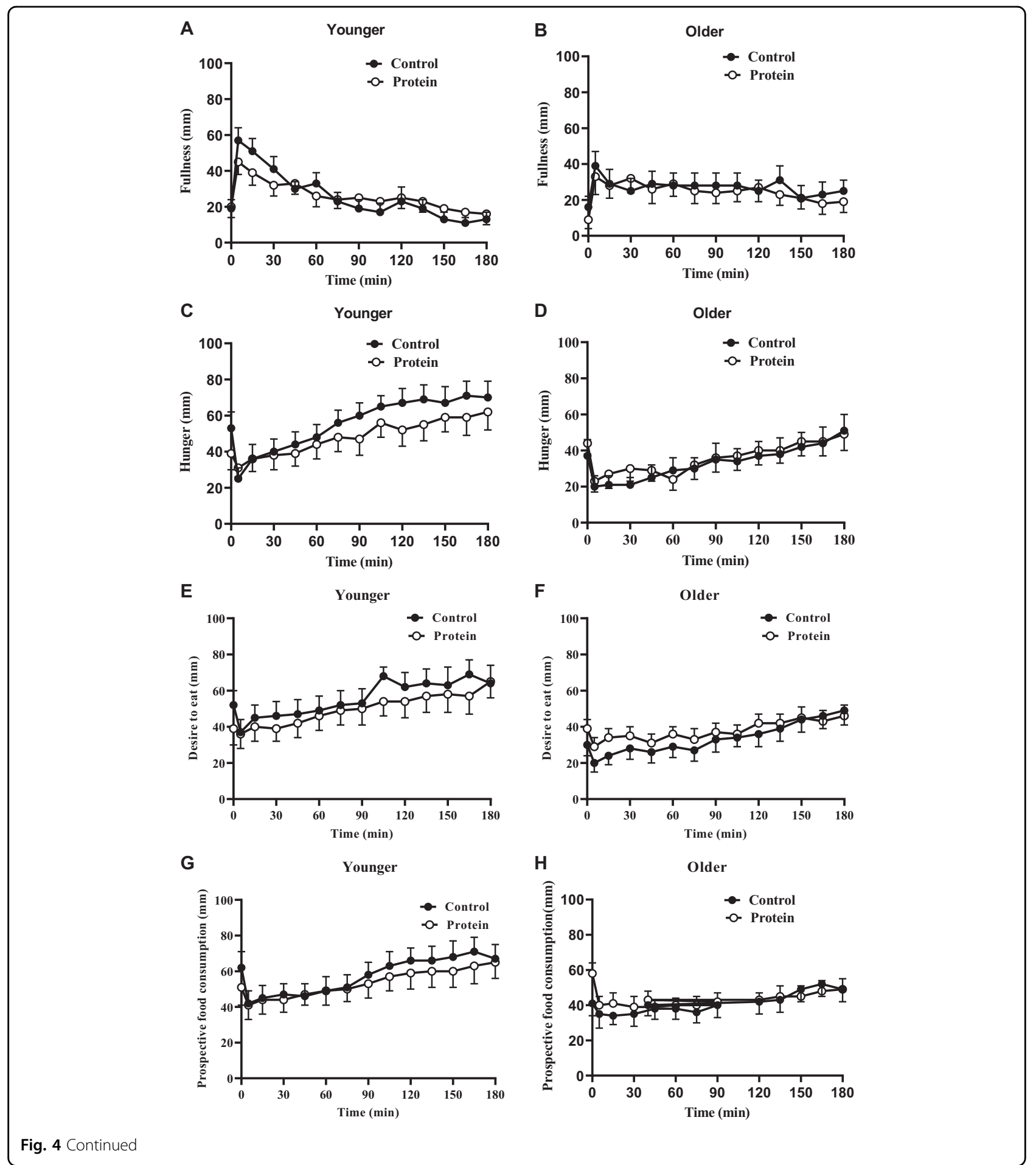

reduced carbohydrate intake $\mathrm{e}^{48-50}$. Many people, however, fail to achieve substantial, long-term weight loss on such diets. One possible explanation for this is that protein is not as satiating in obese as in non-obese individuals. In the present study we examined the impact of obesity on the satiating effects of protein ingestion ${ }^{33}$. In our previous study of young, non-obese men (mean BMI $23 \mathrm{~kg} / \mathrm{m}^{2}$ ) we showed that a $30 \mathrm{~g}$ whey protein drink significantly suppressed ad libitum energy intake at a test meal $3 \mathrm{~h}$ later by $17 \%$ compared to control day intake. That suppression was associated with reduced appetite ratings. In contrast, in the present study, using the same whey dose and study protocol, the protein 


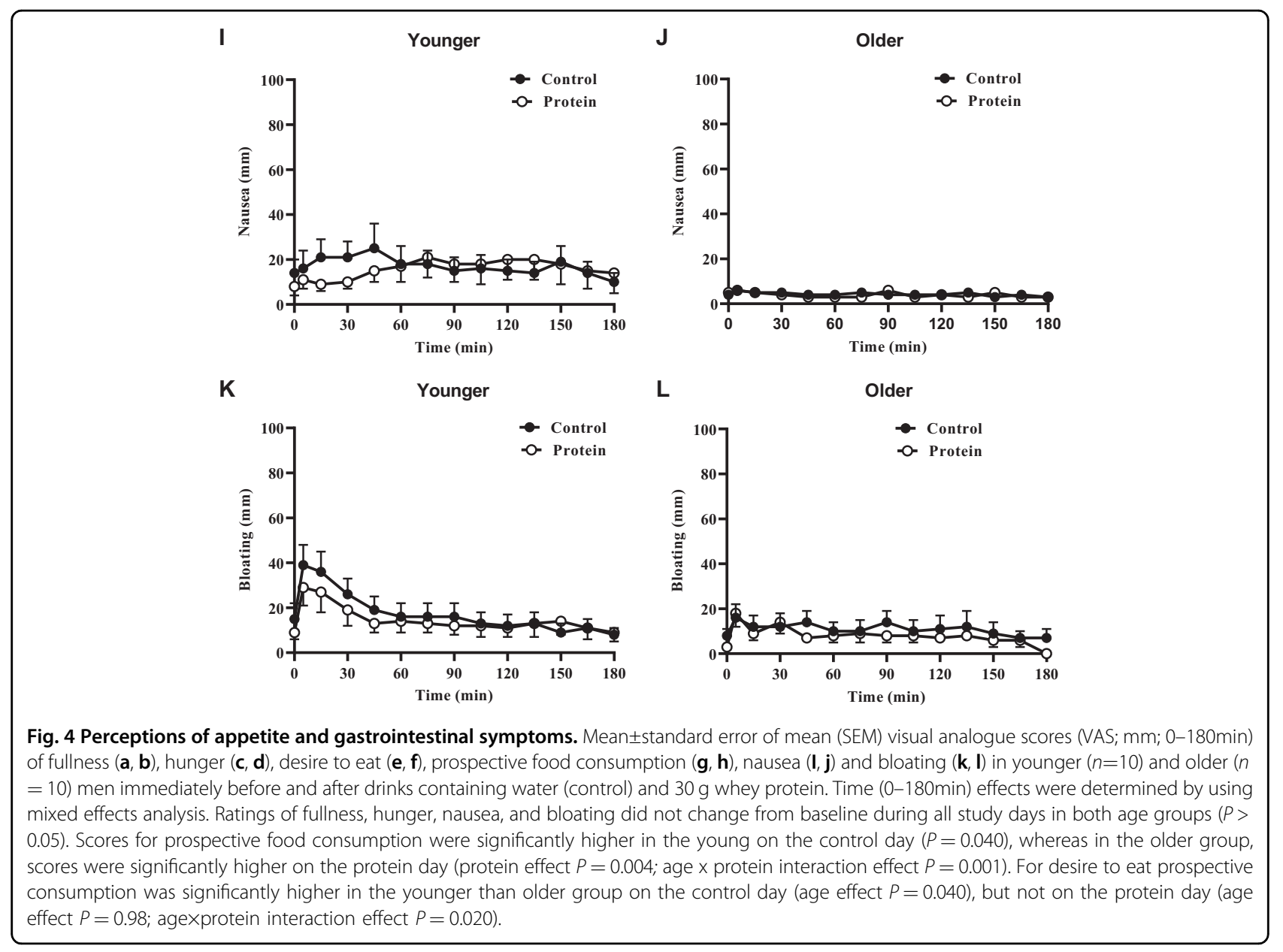

drink suppressed neither energy intake nor appetite ratings in young obese men.

These results contrast with those of Brennan et al. ${ }^{51}$, who reported that high protein meals suppress energy intake in both lean and obese younger men $3 \mathrm{~h}$ after an energy preload. While the energy preloads in that study were larger than we employed ( $213 \mathrm{kcal}$ vs. $120 \mathrm{kcal})$, and administered as a fat, protein and carbohydrate mixture, we have reported previously that pure whey drinks of $280 \mathrm{kcal}$ and mixed macronutrient drink of $504 \mathrm{kcal}$ protein $(280 \mathrm{kcal})$, carbohydrate $(112 \mathrm{kcal})$ and fat $(112 \mathrm{kcal})$ drinks also did not suppress voluntary energy intake at $3 \mathrm{~h}$ in non-obese older men ${ }^{16}$. The preloads in Brennan et al. were solid food (a meat and pasta dish), compared to a whey drink in our study. There is evidence that drinks are less satiating than solid foods of the same nutrient composition ${ }^{51}$. Mourao et al., for example, reported greater ad libitum energy intake after drinks than solid food of comparable energy content ${ }^{52}$. These results are consistent with the possibility of a reduced satiating effect of liquid vs. solid protein. This would support the use of increased oral protein in solid rather than liquid form when the intention is to promote weight loss. Nevertheless, the whey protein drink did suppress appetite and food intake in young, non-obese men in our previous study, an effect not present in the obese young men in this study. These results suggest that obesity may blunt the satiating effects of protein, at least whey protein, and that these effects of obesity may be similar to those of physiological ageing; both healthy ageing and obesity have been associated with a loss of suppression of subsequent food intake by a whey drink.

The mechanism(s) by which obesity blunts the satiating effects of whey protein are not known. Blood glucose concentrations were predictably higher in the older than younger men, but not affected by protein ingestion, as in our previous study of non-obese men ${ }^{33}$, suggesting that glucose was not involved.

Gastric emptying was slowed by ingestion of the whey protein in both younger and older men with no difference between them. Despite this, subsequent food intake was suppressed by whey in neither age group. This suggests, at least under these study conditions, that gastric distension due to retention of the protein load in the stomach and delayed entry of test drink into the small intestine, did not 
affect appetite and food intake. To allow a comprehensive assessment of gastric emptying the test meal was started 180 min after the study drink, by which time the stomach was almost completely empty. It is possible that if the test meal was given earlier, when the difference between the study days in how much drink remained in the stomach was greater, there may have been reduced food intake on the whey drink day and an association between food intake and gastric emptying. Nevertheless, further evidence for the lack of such an association is provided by the results of our previous study in non-obese men ${ }^{33}$, in which gastric emptying was markedly slowed by the whey drink in both older and young men, with almost complete emptying of the drink from the stomach before buffet meal ingestion at $180 \mathrm{~min}$. In that study, there was a reduction in ad libitum energy intake in the non-obese young men, suggesting that slowing of gastric emptying by protein ingestion is not involved in the satiating effect (or lack of) of the protein drinks under these study conditions.

Increasing age is associated with a physiological reduction in hunger and food intake, the so-called "anorexia of ageing $^{\prime 41,53}$. Consistent with that reduction, the older subjects consumed about $20 \%$ less energy in this study than the younger subjects, although that reduction was not statistically significant. On average, body weight decreases after about age 60-70 years. Much of the weight lost is lean tissue, including skeletal muscle and bone ${ }^{54,55}$. Muscle loss can be marked, particularly when pathological processes are superimposed, and can lead to sarcopaenia and frailty. One way to prevent this skeletal muscle loss, and thus preserve function and quality of life, is with dietary protein supplements, that can help maintain lean body mass and improve health ${ }^{56}$. In contrast, when body weight is deliberately lost with energy-reduced diets, lean tissue is lost as well as fat. This may have adverse effects in older people with baseline low muscle mass. The results of this and our previous acute studies suggest that protein supplementation as whey protein drinks can be given to older people as an aid to skeletal muscle preservation and even augmentation, without risk of appetite suppression and weight loss. Conversely, such protein drinks are likely to have little effect to promote weight loss in overweight, older people trying to lose weight, and are likely to be even less effective than in younger adults. Longer term studies in both obese and non-obese older adults evaluating the effects on appetite and food intake of increased protein intake in solid foods would be of interest.

Limitations of this study include the relatively modest subject numbers and the use of only one dose of whey protein. We did not assess the subjects' perceptions of taste and/or pleasantness of the drinks. Gastric emptying rate was measured indirectly by $2 \mathrm{D}$ Ultrasound. 3D ultrasonography, which we have used previously ${ }^{33,57,58}$ is probably more accurate in non-obese people, but was not used here as the results are less reliable in obese individuals due to tissue layers. Scintigraphy is the 'gold standard' technique for measurement of gastric emptying but was not available for this study. We studied only men, as they appear to have the greatest ability to regulate energy intake in response to energy manipulation ${ }^{34}$. The results do not necessarily apply to women.

In summary a $30 \mathrm{~g}$ whey protein drink did not suppress appetite or energy intake in obese younger or older men. We speculate that obesity might mimic the effects of ageing to inhibit responses to protein. The use of liquid whey supplementation is unlikely to be helpful as a weight loss strategy in men of any age. Liquid whey protein supplements, the use of which may be of benefit for the preservation of function in older people, are unlikely to suppress food intake in older people of any weight.

\section{Acknowledgements}

We thank K.L. for statistical support, Judith Wishart, and Scott Standfield for technical assistance in the performance of biochemical assays and Penelope Fitzgerald for preparation of test drinks. The CRE in Translating Nutritional Science to Good Health is supported by The Hospital Research Foundation. The research was funded by grants provided by the Royal Adelaide Hospital Research

Committee and the Australian Society of Parenteral and Enteral Nutrition (AUSPEN). S.S. was supported by a Royal Adelaide Hospital Florey Fellowship (\#2129) and K.L.J. by the University of Adelaide William T Southcott Research Fellowship. Neither the Royal Adelaide Hospital Research Committee, nor AuSPEN provided any input in the design, implementation, analysis or interpretation of the data.

\section{Author details}

${ }^{1}$ Adelaide Medical School and Centre of Research Excellence in Translating Nutritional Science to Good Health, The University of Adelaide, Adelaide, Royal Adelaide Hospital, South-Australia, SA, Australia. ${ }^{2}$ Riddet Institute, Massey University, Palmerston North, New Zealand. ${ }^{3}$ Centre for Nutrition, Department of Clinical Medicine, University of Bergen, Bergen, Norway. ${ }^{4}$ Department of Medicine, Haukeland University Hospital, Bergen, Norway. ${ }^{5}$ Faculty of Health Sciences and Medicine, Bond University, Gold Coast, Queensland, Australia

\section{Author contributions}

C.G., C.J., and S.S. performed experiments; A.O. and K.L. analysed data; A.O. C.G., T.H. K.L.J., M.H., I.C., and S.S. interpreted results of experiments; A.O prepared figures; A.O. drafted manuscript; A.O., C.G., C.J., K.L., T.H., K.L.., M.H., I.C., and S.S. approved final version of manuscript; C.G., K.L., T.H., K.L.., M.H., I.C., and S.S. edited and revised manuscript; C.G., K.L., K.L.., M.H., I.C., and S.S. conception and design of research.

\section{Conflict of interest}

The authors declare that they have no conflict of interest.

\section{Publisher's note}

Springer Nature remains neutral with regard to jurisdictional claims in published maps and institutional affiliations.

Received: 5 April 2020 Revised: 26 August 2020 Accepted: 7 September 2020

Published online: 02 October 2020

\footnotetext{
References

1. Mokdad, A. H. et al. Prevalence of obesity, diabetes, and obesity-related health risk factors, 2001. JAMA 289, 76-79 (2003).

2. Flegal, K. M., Carroll, M. D., Ogden, C. L. \& Curtin, L. R. Prevalence and trends in obesity among US adults, 1999-2008. JAMA 303, 235-241 (2010).

3. Huse, O. et al. Obesity in Australia. Obes. Res Clin. Pract. 12, 29-39 (2018).

4. Petermann-Rocha, F. et al. Factors associated with sarcopenia: a cross-sectional analysis using UK Biobank. Maturitas 133, 60-67 (2020).
} 
5. Yu, C.-Y., Woo, A., Emrich, C. T. \& Wang, B. Social Vulnerability Index and obesity: an empirical study in the US. Cities 97, 102531 (2020).

6. Janssen, I. Morbidity and mortality risk associated with an overweight BMI in older men and women. Obes. (Silver Spring) 15, 1827-1840 (2007).

7. Arterburn, D. E., Crane, P. K. \& Sullivan, S. D. The coming epidemic of obesity in elderly Americans. J. Am. Geriatr. Soc. 52, 1907-1912 (2004).

8. Roubenoff, R. Sarcopenic obesity: the confluence of two epidemics. Obes. Res. 12, 887-888 (2004).

9. Villareal, D. T., Apovian, C. M., Kushner, R. F. \& Klein, S. American Society for Nutrition; NAASO, The Obesity Society, Obesity in older adults: technical review and position statement of the American Society for Nutrition and NAASO, The Obesity Society. Obes. Res. 13, 1849-1863 (2005).

10. Villareal, D. T. et al. Weight loss, exercise, or both and physical function in obese older adults. N. Engl. J. Med. 364, 1218-1229 (2011).

11. Kyrou, I. \& Tsigos, C. Obesity in the elderly diabetic patient: is weight loss beneficial? No. Diabetes Care 32(Suppl 2), S403-S409 (2009).

12. Giezenaar, C. et al. Ageing is associated with decreases in appetite and energy intake-a meta-analysis in healthy adults. Nutrients 8, 28 (2016).

13. Giezenaar, C. et al. Effect of age on blood glucose and plasma insulin, Glucagon, Ghrelin, CCK, GIP, and GLP-1 responses to whey protein ingestion. Nutrients 10 (2017).

14. Giezenaar, C. et al. Dose-dependent effects of randomized intraduodenal whey-protein loads on glucose, gut hormone, and amino acid concentrations in healthy older and younger men. Nutrients 10 (2018).

15. Giezenaar, C. et al. Effects of randomized whey-protein loads on energy intake, appetite, gastric emptying, and plasma gut-hormone concentrations in older men and women. Am. J. Clin. Nutr. 106, 865-877 (2017).

16. Giezenaar, C. et al. Effects of substitution, and adding of carbohydrate and fat to whey-protein on energy intake, appetite, gastric emptying, glucose, insulin, ghrelin, CCK and GLP-1 in healthy older men-a randomized controlled trial. Nutrients 10 (2017).

17. Soenen, S. et al. Effects of intraduodenal protein on appetite, energy intake, and antropyloroduodenal motility in healthy older compared with young men in a randomized trial. Am. J. Clin. Nutr. 100, 1108-1115 (2014).

18. Evans, W. J. \& Campbell, W. W. Sarcopenia and age-related changes in body composition and functional capacity. J. Nutr. 123, 465-468 (1993).

19. Beals, J. W., Burd, N. A., Moore, D. R., van Vliet S. Obesity alters the muscle protein synthetic response to nutrition and exercise. Front. Nutr. 6 (2019).

20. Batsis, J. A. Obesity in the older adult: special issue. J. Nutr. Gerontol. Geriatr. 38, 1-5 (2019).

21. Li, Z. \& Heber, D. Sarcopenic obesity in the elderly and strategies for weight management. Nutr. Rev. 70, 57-64 (2012).

22. Blaum, C. S., Xue, Q. L., Michelon, E., Semba, R. D. \& Fried, L. P. The association between obesity and the frailty syndrome in older women: the women's health and aging studies. J. Am. Geriatr. Soc. 53, 927-934 (2005).

23. Lapane, K. L. \& Resnik, L. Obesity in nursing homes: an escalating problem. J. Am. Geriatr. Soc. 53, 1386-1391 (2005).

24. Villareal, D. T., Banks, M., Siener, C., Sinacore, D. R. \& Klein, S. Physical frailty and body composition in obese elderly men and women. Obes. Res. 12, 913-920 (2004).

25. Zizza, C. A., Herring, A., Stevens, J. \& Popkin, B. M. Obesity affects nursing-care facility admission among whites but not blacks. Obes. Res. 10, 816-823 (2002)

26. Elkins, J. S. et al. Midlife obesity and long-term risk of nursing home admission. Obes. (Silver Spring) 14, 1472-1478 (2006).

27. Soenen, S. \& Westerterp-Plantenga, M. S. Proteins and satiety: implications for weight management. Curr. Opin. Clin. Nutr. Metab. Care 11, 747-751 (2008).

28. Soenen, S., Hochstenbach-Waelen, A. \& Westerterp-Plantenga, M. S. Efficacy of alpha-lactalbumin and milk protein on weight loss and body composition during energy restriction. Obes. (Silver Spring) 19, 370-379 (2011).

29. Bray, G. A. \& Siri-Tarino, P. W. The role of macronutrient content in the diet for weight management. Endocrinol. Metab. Clin. North Am. 45, 581-604 (2016).

30. Blatt, A. D., Roe, L. S. \& Rolls, B. J. Increasing the protein content of meals and its effect on daily energy intake. J. Am. Diet. Assoc. 111, 290-294 (2011).

31. Devries, M. C. \& Phillips, S. M. Supplemental protein in support of muscle mass and health: advantage whey. J. Food Sci. 80(Suppl 1), A8-a15 (2015).

32. Pennings, B. et al. Whey protein stimulates postprandial muscle protein accretion more effectively than do casein and casein hydrolysate in older men. Am. J. Clin. Nutr. 93, 997-1005 (2011).
33. Giezenaar, C. et al. Lesser suppression of energy intake by orally ingested whey protein in healthy older men compared with young controls. Am. J. Physiol. Regul. Integr. Comp. Physiol. 309, R845-R854 (2015).

34. Ryan, A. T. et al. Intraduodenal protein modulates antropyloroduodenal motility, hormone release, glycemia, appetite, and energy intake in lean men. Am. J. Clin. Nutr. 96, 474-482 (2012).

35. Hutchison, A. T. et al. Acute load-dependent effects of oral whey protein on gastric emptying, gut hormone release, glycemia, appetite, and energy intake in healthy men. Am. J. Clin. Nutr. 102, 1574-1584 (2015).

36. Marathe, C. S., Rayner, C. K., Jones, K. L. \& Horowitz, M. Relationships between gastric emptying, postprandial glycemia, and incretin hormones. Diabetes Care 36, 1396-1405 (2013)

37. Hunt, J. N. \& Stubbs, D. F. The volume and energy content of meals as determinants of gastric emptying. J. Physiol. 245, 209-225 (1975).

38. Hunt, J. N. A possible relation between the regulation of gastric emptying and food intake. Am. J. Physiol. 239, G1-G4 (1980).

39. Wright, R. A., Krinsky, S., Fleeman, C., Trujillo, J. \& Teague, E. Gastric emptying and obesity. Gastroenterology 84, 747-751 (1983).

40. Sturm, K. et al. Energy intake and appetite are related to antral area in healthy young and older subjects. Am. J. Clin. Nutr. 80, 656-667 (2004).

41. Clarkston, W. K. et al. Evidence for the anorexia of aging: gastrointestinal transit and hunger in healthy elderly vs. young adults. Am. J. Physiol. 272 R243-R248 (1997)

42. Horowitz, M. et al. Changes in gastric emptying rates with age. Clin. Sci. (Lond.) 67, 213-218 (1984).

43. Moore, J. G., Tweedy, C., Christian, P. E. \& Datz, F. L. Effect of age on gastric emptying of liquid-solid meals in man. Dig. Dis. Sci. 28, 340-344 (1983).

44. Folstein, M. F., Folstein, S. E. \& McHugh, P. R. Mini-mental state". A practical method for grading the cognitive state of patients for the clinician. J. Psychiatr. Res. 12, 189-198 (1975)

45. Yesavage, J. A. et al. Development and validation of a geriatric depression screening scale: a preliminary report. J. Psychiatr. Res. 17, 37-49 (1982).

46. Hveem, K., Jones, K. L., Chatterton, B. E. \& Horowitz, M. Scintigraphic measurement of gastric emptying and ultrasonographic assessment of antral area: relation to appetite. Gut 38, 816-821 (1996).

47. Parker, B. A. et al. Relation between food intake and visual analogue scale ratings of appetite and other sensations in healthy older and young subjects. Eur. J. Clin. Nutr. 58, 212-218 (2004).

48. Atkins, M., Robert, C. Dr. Atkins' new diet revolution, (Government Institutes, 2002).

49. Sears, B. \& Lawren, B. The Zone: A Dietary Road Map. (Regan Books: New York, NY, 1995).

50. Julia, C. et al. Weight-loss strategies used by the general population: how are they perceived? PLOS ONE 9, e97834 (2014).

51. Brennan, I. M. et al. Effects of fat, protein, and carbohydrate and protein load on appetite, plasma cholecystokinin, peptide $Y$, and ghrelin, and energy intake in lean and obese men. Am. J. Physiol. Gastrointest. Liver. Physiol. 303, G129-G140 (2012).

52. Mourao, D. M., Bressan, J., Campbell, W. W. \& Mattes, R. D. Effects of food form on appetite and energy intake in lean and obese young adults. Int. J. Obes. (Lond.) 31, 1688-1695 (2007).

53. Soenen, S. \& Chapman, I. M. Body weight, anorexia, and undernutrition in older people. J. Am. Med. Dir. Assoc. 14, 642-648 (2013).

54. Morley, J. E. \& Silver, A. J. Anorexia in the elderly. Neurobiol. Aging 9, 9-16 (1988).

55. St-Onge, M. P. \& Gallagher, D. Body composition changes with aging: the cause or the result of alterations in metabolic rate and macronutrient oxidation? Nutrition 26, 152-155 (2010).

56. Lancha, A. H. Jr., Zanella, R. Jr., Tanabe, S. G., Andriamihaja, M. \& Blachier, F. Dietary protein supplementation in the elderly for limiting muscle mass loss. Amino Acids 49, 33-47 (2017).

57. Gentilcore, D., Hausken, T., Horowitz, M. \& Jones, K. L. Measurements of gastric emptying of low- and high-nutrient liquids using 3D ultrasonography and scintigraphy in healthy subjects. Neurogastroenterol. Motil. 18, 1062-1068 (2006)

58. Stevens, J. E. et al. Measurement of gastric emptying of a high-nutrient liquid by $3 \mathrm{D}$ ultrasonography in diabetic gastroparesis. Neurogastroenterol. Motil. 23 (220-5), e113-e114 (2011). 